\title{
THE POLITICAL ECONOMY OF GLOBAL INEQUALITY: AN ECONOMIC HISTORICAL PERSPECTIVE
}

\begin{abstract}
The aim of this paper is to evaluate how the economic gulf between advanced and less-developed countries might be narrowed by analysing the progress of their economies in historical perspective. It is an important question for the 21st century whether countries in Asia, Africa and Latin America are capable of economic convergence with the West. To answer this question we need an understanding of both economics and history. It has often been argued that the international distribution of wealth between the rich (industrialised) and poor (primary producing) countries will be narrowed or closed as a result of a trickle-down process from the technologically-advanced countries to the poor countries. This paper analyses this claim using a quantitative methodology built on data from international institutions such as the OECD, IMF and World Bank. It finds that during the last three decades there have been huge economic changes globally: structural arrangements and patterns of trade have changed in both advanced and developing countries. However, while some developing countries have achieved faster growth rates than the advanced economies particularly China, India, Indonesia, and Turkey - most developing countries have not been able to catch up with the economies of the developed world.
\end{abstract}

Keywords: catching-up, convergence, neoliberalism, developed and developing countries, international trade.

JEL Classification: P45, O47.

Kalim Siddiqui, University of Huddersfield, The Business School, Department of Accounting, Finance and Economics, Queensgate, Huddersfield - HD1 3DH, UK, e-mail: k.u.siddiqui@ hud.ac.uk, ORCID: https://orcid.org/0000-0002-7952-4573.

The author would like to thank Barry Pavier and Ian Pitchford for helpful comments and suggestions on an earlier draft of the paper. The author remains solely responsible for the views expressed in this paper. 


\section{Introduction}

In recent years a number of studies have been published about the shift in the balance of power from the West (US, Europe and Japan) to the East (China and India) (IMF 2016, Nayyar 2013, Jacques 2012, Rowthorn 2008). The financial crisis of 2008 uncovered inherent weaknesses in the current international monetary system that contributed to global financial instability, global economic crisis, and to a weak global economy. For developing countries, which rely heavily on international trade and foreign direct investment for growth and economic development, the failure of the global reserve system to ensure sufficient international liquidity caused them to suffer from spill-over effects of global financial instability and economic crisis.

The aim of this study is to critically examine the on-going discussions on global inequality. It concentrates on the international distribution of wealth between the "industrialised" and "primary" producing countries and the claim that the benefit of technical progress in the advanced (developed) economies would trickle down to the poor countries.

Since their independence in the 1950s and 1960s, the developing countries" share of global GDP has risen to over 44\% in 2014, double that in the 1970s. The industrial sector in the developing countries is also increasing and their share of value added in global manufacturing output increased from $13 \%$ in 1970 to more than $45 \%$ by 2014 . However, the region-wise increase in manufacturing output was highly unequally distributed (IMF 2016, Anievas \& Nisancioglu 2015). For instance, Latin America's manufacturing share of global GDP has only marginally increased to $8 \%$ between 1970 and 2015, while for manufacturing share of Africa has remained the same, i.e. less than $3 \%$ for this period. Africa's share in manufacturing value added in 2015 was only $2 \%$, just as it was in 1970 (UNIDO 2016).

As the Chinese and Indian economies are quickly catching-up with the advanced economies (Siddiqui 2018b), both are re-emerging as major contributors to global output growth in the $21^{\text {st }}$ century. China has become the second largest economy after the US, which is a remarkable development of the $21^{\text {st }}$ century (Jacques 2012, Siddiqui 2009). Moreover, the patterns of trade are changing as well. For example, the share of manufactures in developing countries' exports rose from $12 \%$ in 1980 to $64 \%$ by 2015 ; nearly half of this consisted of medium and high technology products. Another key development has been the rise of services in the export 
components of the developing countries, such as information technology and e-commerce.

Global income inequality is measured in a number of ways: the first method of estimation adopted is inter-country inequality, which treats each country as individual and the inequality measured is that of the distribution of per capita GDP among countries. The second method is supposed to be slightly better as it takes into account the population size of a country. The third estimation method takes into account the inequality of the world income distribution by combining inequality distribution in individual countries together with per capita income.

The primary focus of this study is the causes of and trends in global economic inequality as illustrated by the date from a selected group of nations.

Section 1 presents an introduction to the topic; Section 2 discusses economic transformation in the colonies; Section 3 analyses economic convergence and divergence between the period of 1820 and 1950; Section 4 examines the issue of free trade; Section 5 analyses globalisation and economic liberalism; Section 6 looks at whether the developing world is catching-up with the developed world and finally Section 7 offers some conclusions.

\section{Economic Transformation in the Colonies}

There is no doubt that capitalism powered by rapid industrial growth laid the foundation for increased productivity and higher incomes in the West. However, capitalism as it is manifested in a handful of advanced economies does not provide a full picture of its impact. The Eurocentric view does not include various other factors which contributed towards the development of capitalism, such as vast capital accumulation from slavery; from the plundering of territories, and from colonisation. The British rulers of India, for instance, did not settle but were only interested in transferring wealth from India to support their own development of capitalism and industrialisation in Britain. As a result, countless Indian soldiers died to protect the British Empire's expropriation of Indian money and materials (Siddiqui 2017a). Among the most important questions about this period is the nature of the British advantage over other European countries in their quest to become the major industrial country and the foremost colonial power. That advantage was control of India, which not only provided British companies with vast markets for their finished products and raw 
materials, but also provided money, resources, and soldiers. The $19^{\text {th }}$ century Conservative Party Prime Minister Lord Salisbury emphasised that India was: "an English barrack in the oriental seas from which we may draw any number of troops without paying for them" (quoted in Arrighi 2007, p. 136). It was also due to Indian soldiers that Britain was able to keep a large presence in the Pacific during World War II as the campaign against Japan progressed.

The colonisation of the economies of Asia, Africa, and Latin America in the late $18^{\text {th }}$ and early $19^{\text {th }}$ century put a break on their internally-initiated progressive reforms and structural changes. It also imposed de-industrialisation, reoccurrences of famine, and forced integration of their economies with those of the occupying powers. To strengthen their occupation regimes various compromises were made with the established pre-capitalist and reactionary forces, and policies of "divide and rule" brought untold suffering to people in the colonies (Bagchi 1984).

Let us look at the pre-colonial economy: in 1750, prior to colonisation, India's share of the world economy was $23 \%$ of total output, but nearly two centuries after British rule, it had dropped to just 4\% in 1947 (Maddison 1998). Some economic historians agree that India and China during the pre-colonial period were leading economies (Bagchi 1984, Maddison 2003). Moreover, Bairoch (1983) indicates that in 1750 income levels per capita in Europe were slightly lower than those in South Asia and China, though others have suggested that in 1750 the levels of development and per capita income in Europe and Asia were broadly similar (Parthasarathi 2011, Pomeranz 2000, pp. 36-41). It is interesting to look beyond per capita income towards other social indicators. The available evidence suggests that life expectancy and the birth rate were both similar in Europe and Asia in 1750. Life expectancy rose to 36 years in 1820, to 46 years in 1900 in Europe, while in the colonies it remained lower i.e. 24 years in 1820 and 26 years in 1900 (Bagchi 1984, Bairoch 1983).

The level of industrialisation is important because of its impact on agricultural production and employment, the development of technology, the increase in productivity, and also its spill-over effects on the rest of the economy. Therefore, it is important to analyse this issue. During the $17^{\text {th }}$ and $18^{\text {th }}$ centuries, the world economy was characterised by a flow of manufactured goods from China and India to Europe. These goods were paid for in silver and gold by European traders. Spices and cotton textiles from India, and tea, porcelain, and silk from China were exported to Europe (Frankopan 2015). During the $19^{\text {th }}$ century the military defeat of India and 
partial colonisation of China, which coincided with the industrial revolution in Britain, changed all of this.

European colonial expansion began much earlier, in the 16th century, as a result of Spain and Portugal's search for silver, spices, and slaves from Africa and Asia. Colonisation plantations and mining were established soon afterwards and encouraged as a source of profitable commodities such as sugar, cotton, maize and tobacco - all under the control of European businesses. The policy of "divide and rule" was followed and people became increasingly divided by supposed racial characteristics and colour, which inflated hatred, prejudice, and violence to a level unknown in the past. These business activities and the forcible extraction of immense quantities of silver from the Americas gave Europeans unprecedented sources of capital accumulation which were then re-invested back into Europe to pay for Chinese imports and military conflicts. Moreover, this mercantilism and expansion of trade had full state patronage. Imports of spices, textiles, tea, silk, and porcelain from India and China were paid for by silver and other precious metals looted from the Americas. In the late $16^{\text {th }}$ century the Dutch defeated Spain and Portugal and then in the $18^{\text {th }}$ century the British navy emerged as the strongest power in Europe. England also extended full state protection to its merchant ships (Chang 2002). During the $18^{\text {th }}$ century in England a rapid economic transformation took place, i.e. the proportion of the population dependent on agriculture for their livelihood fell from $75 \%$ to $35 \%$ in a very short period and the importance of trade and manufacturing grew in terms of providing both employment and income (Parthasarathi 2011). Similar structural changes were observed in the Netherlands and Belgium, but at a much slower pace. Later a more modest decline of the agriculture sector was also observed in France, Germany, Italy, and Spain. In England this rapid structural change also meant a rise in urbanisation and the expansion of trade accompanied by an increase in literacy and further commercialisation of agriculture (Saville 1969). However, during the mid- $18^{\text {th }}$ century exports from China and India were rising and were very competitive because in comparison to Europe they had efficient markets and stronger property rights (Parthasarathi 2011).

There are more similarities between Asia and Western Europe in the mid- $18^{\text {th }}$ century than differences, when China and India together were able to contribute $50 \%$ of the world output (Anievas \& Nisancioglu 2015). The question thus arises as to why Western Europe and not Asia succeeded in the industrial revolution. There are a number of reasons. The shortage of wood in England caused by deforestation compelled the 
early use of coal on a large scale; state assistance was extended to spread use of technology in mining, and a number of policies were undertaken to protect infant enterprises such as the wool industry. The state protected domestic industries in their nascent and vulnerable stages (Chang 2002). These active policy measures at the domestic level coincided with military success overseas over the 1688-1780 period. Finally, in 1757, Siraj-u-Daulah, the last independent Nawab of Bengal, was defeated in the Battle of Plassey. This presented the British with a major opportunity to plunder and loot all of Bengal systematically (Siddiqui 1990).

The British ruled in India from 1757 to 1947. During this period income growth was negligible and life expectancy declined. Moreover, during the second half of the $19^{\text {th }}$ century per capita income fell in India by $50 \%$ (Hyndman 1919, p. 22; Davis 2001). This was the direct result of the colonial policy of imposition of monoculture cultivation of indigo and opium for export to China, and tea, raw cotton, and wheat for export to Britain. The land tax was raised to very high levels and this led to small peasants abandoning subsistence agriculture based on rice for cultivation of indigo and opium. In wheat production market forces determined the price and India continued to export wheat to Europe even during famines (Davis 2001). The opening of the Suez Canal further reduced transport costs, which boosted wheat exports from India, especially the Punjab and Central Provinces, with the result that the export of wheat went up by $300 \%$ between 1875 and 1900 (Davis 2001, p. 299).

In fact, during the time of famines in India there was no government initiative to help to distribute food to starving people. Following laissez-faire policies the colonial government refused to provide any rescue packages, while at the same time the Indian government mobilised resources to fund war in Afghanistan. Moreover, the so-called modernisation process during the colonial regime was slow and uneven across sectors and regions (Siddiqui 1990). Despite limited economic changes the colonial regime reinforced pre-capitalist production relations in the economy, which resulted in structural retrogression whereby the dynamic potential for accumulation and development associated with capitalism in Europe was systematically undermined. The cultivation of export crops was designed with the sole aim to benefit the colonial regime and not the peasantry. The constant need for tribute and the rising cost of colonial wars required constant increases in land revenue, which in turn resulted in frequent famines and untold deaths and deprivation in India (Davis 2001, Siddiqui 2014). The land revenue demand also ceased to adjust with fluctuations in output. Therefore, 
the British imposed changes in land ownership and property rights, which contributed to greater insecurity for the peasantry by exposing them to the mercy of merchants-cum-money lenders and absentee landlords. The regions in eastern India suffered the most adverse effects of colonial rule. As Bagchi (1984) argues: "India ceased to be a leading manufacturing country of the pre-capitalist era and was reduced to the position of a supplier of agricultural goods and raw materials to the industrialising economies of the West, particularly Britain (...) The long process of de-industrialisation of India started with the catastrophic disappearance of cotton manufacturing from the list of exports of India (...)" (Bagchi 1984, p. 82).

Frequent famines gave the opportunity to money lenders and landlords to uproot peasants and acquire more land. This phenomenon of absentee landowners taking over the ownership title from the peasants and converting them into debt bondage and tenancy had hitherto never been witnessed in India. As a result, a new parasitic stratum of absentee landowners grew, while the amount of rural indebtedness increased rapidly (Siddiqui 2014). As Davis (2001) argues: "the forcible incorporation of smallholder production into commodity and financial circuits controlled from overseas tended to undermine traditional food security. Recent scholarship confirms that it was subsistence adversity (high taxes, chronic indebtedness, inadequate acreage (...)), not entrepreneurial opportunity that typically promoted the turn to cash crop cultivation. Rural capital in turn tended to be parasitic rather than productive as rich landowners redeployed fortunes that they built during the export booms into usury [exorbitant rents] and crop brokerage (...) commercialization went hand in hand with pauperization without any silver lining of technical change or agrarian capitalism" (Davis 2001, pp. 289-90).

A similar situation was experienced in Egypt. For instance, during the Muhammad Ali regime, between 1820 and 1840, Egypt attempted to modernise its economy through industrialisation. To finance this the country relied on external borrowings. The areas chosen to receive state subsidies were the new strain of cotton seeds and accompanying credits to farmers who were willing to cultivate this new long strain cotton. The government was a monopoly buyer of raw cotton, which encouraged nepotism and corruption. The government also built a number of textile industries, which focused on foreign markets and exports. Britain's manufacturers saw this as a potential threat. To undermine such Egyptian policies, Britain encouraged Turkey to attack Egypt. Muhammad Ali also experienced internal challenges and opposition to his policies and as a result 
Ali was weakened (Cain 2006). Finally, as Kevan Harris (2016, p. 5) argues: "[in 1840] British and Austrian navies cut off Egyptian supply lines and entered Alexandria's waters. Under duress, Ali signed series of capitulations which opened Egyptian markets, dismantled its manufacturing base and defanged its military. Egypt experienced rapid underdevelopment, becoming an exporter of raw commodities and an importer of European manufacturers for the next century". Under pressure, Ali relented and granted British manufactured products free access to Egyptian markets. Europeans were also allowed to own land and resources in Egypt. As a result, Egypt was transformed into a supplier of raw materials rather than a producer and exporter of industrial products (Siddiqui 2015b, Cain 2006). As Stavrianos (1981, p. 221) argues: "Under the protection of the capitulatory treaties [of war with Turkey and Britain] European speculators and adventurers were free to operate in Egypt outside the jurisdiction of the native courts and subject only to consular control. Many grew rich by smuggling opium and tobacco and invariably were protected by the foreign consuls (...) These foreigners, who were completely exempt from taxation, also served as agents in arranging for loans and contracts on extortionist terms. In 1873, for example, [the Egyptian government] accepted a loan at the face value of $£ 32$ million, but after heavy commissions and discounts received only $£ 9$ million".

Of the policy changes from mercantilism to overseas expansion that underlay British industrial supremacy, Engels wrote: "It was under the fostering wing of protection that the system of modern industry - production by steam-moved machinery - was hatched and developed in England during the last third of the $18^{\text {th }}$ century. And, as if tariff protection as not sufficient, the wars against the French Revolution helped to secure England the monopoly of new industrial methods. For more than 20 years, English men-of-war [fighting ships] cut off the industrial rivals of England from their respective colonial markets, while they forcibly opened these markets to English commerce. The secession of the South American colonies from the rule of their European mother countries, the conquest by England of all French and Dutch colonies worth having, the progressive subjugation of India turned the people of all these immense territories into customer of English goods. England thus supplemented the protection she practised at home by free trade she forced upon her possible customers abroad; and thanks to this happy mixture of both systems, at the end of the war, in 1815 , she found herself, (...) in possession of virtual monopoly of the trade of the world" (Engels 1990, p. 522). 
In Britain the government fully supported the policies of modernisation and expansion of industries by promoting technology, raising productivity, and by encouraging the efficient use of production during the early phase of industrialisation. Similar polices of active state support were applied later on in Germany and France to industrialise their countries. In all of the Western European countries and later on in the US, Japan, and South Korea the process of industrialisation was fully supported by the state through tariff protection and through active industrial policies (List 1966, Amsden 2001). In contrast to this, in colonial India no such policies were adopted, and no efforts were made to protect domestic industries. As a result, we found a steady productivity decline with de-industrialisation and de-urbanisation in India and in other major Asian countries, which took place in the $18^{\text {th }}$ and $19^{\text {th }}$ centuries (Siddiqui 1996, Baran 1957).

\section{Decline or Economic Convergence between 1820 and 1950 ?}

The question arises as to why the developing countries' economies began to decline in the early $19^{\text {th }}$ century. It is widely accepted that the manufacturing sector plays an important role in raising overall productivity. Therefore, we need to examine the developing countries' share of manufacturing output in the global economy in the first quarter in the $19^{\text {th }}$ century. How did this share change during the colonial period? In the 1820 s Asia produced more than half of the world's output when regional economies were not yet fully colonised by the European powers. Thereafter, the industrial revolution and colonialism created an imbalanced and unequal world.

Asia had dominated in terms of GDP as late as 1800 largely because of two populous countries, China and India. These together accounted for $50 \%$ of the world population and $50 \%$ of world GDP. Europe, Russia, and Japan were far less important economically and their share in world output was far from being dominant. In 1820 the South (developing countries) accounted for $60 \%$ of global GDP and $74 \%$ of the world's population. The per capita income of these countries was $85 \%$ of the global average of US\$ 666 (in 1990 prices). China and India, the two largest economies, together accounted for nearly 50\% global of GDP and nearly $57 \%$ of the world's population (Maddison 2003).

However, by the 1820 s, while the Asian population remained the same, its share in world GDP declined modestly. However, for the same period, the European and Japanese share in world GDP increased. Maddison's 
estimates on population and output indicate that between 1820 and 1950 the "West" share in the world population increased from one-fourth to one-third, while its share in world output doubled from $37 \%$ to $73 \%$, which was a game changer, and its consequences became far longer than initially envisaged (Maddison 2003). For the same period (i.e. from 1820 to 1950) the "South" share in the world population declined from three-fourths to two-thirds, but its share in world output declined sharply from $63 \%$ to $27 \%$. This transformation of the world economy happened in a short period of just 130 years. As a result this sharp decline, which led to the creation of a new international division of labour, the South was economically marginalised and the West established a dominant position (Anievas \& Nisancioglu 2015).

Maddison $(2003,1998)$ has estimated the long term changes in the world population and world income for selected years. His estimates are based on a specific method where international prices have been calculated to facilitate cross-country comparisons. Maddison's method is widely used and seems to provide a comprehensive source of historical statistics.

Table 1, derived from Maddison's data on GDP, provides evidence on the distribution of population and output in the world economy for selected years. Among the Asian countries, China and India were prominent economies; the share of the GDP of Western Offshoots includes the US, Canada, Australia and New Zealand, and the former USSR (ex-Soviet Union). As indicated in Table 1, the share of China and India together in world output was nearly $50 \%$ in 1820 , declining sharply to $8.8 \%$ in 1950 . In contrast to this, the share of Western Europe and Western Offshoots together in world output rose dramatically from $24.8 \%$ in 1820 to $56.9 \%$ in 1950.

Maddison's (2003) estimates are also broadly supported by others. For example, Bairoch (1983) estimated GNP for selected years in the 1750-1950 period and divided the countries into two groups - the first group included Asia, Africa, and Latin America, and the second group included Europe, Japan, and North America. His estimates are based in 1960 US\$ prices and adjusted for differences in PPP. Bairoch found that the share of the former group in world GDP was $69 \%$ in 1830, and came down to $57.4 \%$ in 1860, which is higher than Maddison's estimate of $63 \%$ in 1820 and $42.6 \%$ in 1870 . Bairoch $(1983,1993)$ estimates that the share of the developing countries further dropped to $38.3 \%$ in 1900 and $33.5 \%$ in 1913. This figure is closer to Maddison's $32.6 \%$ in 1900 and $29.6 \%$ in 1913. Their share declined further to $30.2 \%$ in 1928 and $27.5 \%$ in 1950. This figure is very close to Maddison's estimate of 29\% in 1940 and $27.1 \%$ in 1950 (Maddison 2003). 
Table 1. Distribution of Population and GDP in the World Economy, 1600-1950 (in \%)

\begin{tabular}{l|c|c|c|c|c|c|c|c|c|c}
\hline \multirow{2}{*}{ Specification } & \multicolumn{4}{|c|}{ World population } & \multicolumn{5}{c}{ World GDP } \\
\cline { 2 - 12 } & 1600 & 1700 & 1820 & 1900 & 1950 & 1600 & 1700 & 1820 & 1900 & 1950 \\
\hline China & 28.8 & 22.9 & 36.6 & 25.6 & 21.6 & 29.0 & 22.3 & 33.0 & 11.1 & 4.6 \\
\hline India & 24.3 & 27.3 & 20.1 & 18.2 & 14.2 & 22.4 & 24.5 & 16.1 & 8.6 & 4.2 \\
\hline Africa & 9.9 & 10.1 & 7.1 & 7.0 & 9.0 & 7.0 & 6.9 & 4.5 & 3.4 & 3.8 \\
\hline Latin America & 1.5 & 2.0 & 2.1 & 4.1 & 6.5 & 1.1 & 1.7 & 2.2 & 3.6 & 7.8 \\
\hline $\begin{array}{l}\text { Western } \\
\text { Europe }\end{array}$ & 13.3 & 13.5 & 12.8 & 14.9 & 12.1 & 19.8 & 21.8 & 22.9 & 34.2 & 26.2 \\
\hline $\begin{array}{l}\text { Western } \\
\text { Offshoots }\end{array}$ & 3.0 & 3.1 & 3.5 & 5.5 & 7.0 & 0.3 & 0.2 & 1.9 & 17.6 & 30.7 \\
\hline $\begin{array}{l}\text { Eastern } \\
\text { Europe }\end{array}$ & 3.3 & 3.1 & 3.5 & 4.5 & 3.5 & 2.8 & 3.1 & 3.6 & 5.2 & 3.5 \\
\hline Former USSR & 3.7 & 4.4 & 5.3 & 8.0 & 7.1 & 3.4 & 4.4 & 5.4 & 7.8 & 9.6 \\
\hline Japan & 3.3 & 4.5 & 3.0 & 2.8 & 3.3 & 2.9 & 4.1 & 3.0 & 2.6 & 3.0 \\
\hline Total & 100 & 100 & 100 & 100 & 100 & 100 & 100 & 100 & 100 & 100 \\
\hline
\end{tabular}

Source: Maddison (2003, 1998), Nayyar (2013, pp. 13-15).

In short, the differences widened between the developing and advanced economies from 1820 to 1950 . The developing countries' share in the world population declined from $65 \%$ to $52 \%$, while their share in world GDP fell very substantially from $57 \%$ to merely $16 \%$ for the same period (Maddison 2003). This was largely due to a decline in the economies of China and India. Both countries' share in the world population fell from $56.7 \%$ to $35.8 \%$, while their share in world output fell dramatically from $49.1 \%$ to only $8.8 \%$ between 1820 and 1950 (see Table 1). This was catastrophic for both countries as these were the periods when they suffered European aggression, colonialism, and famines.

Japan's share of the world economy remained stable at 3-4\%, and with the Meiji Restoration in 1868 the country was able to improve its economic and political positions in Asia. At the beginning of the $20^{\text {th }}$ century Japan emerged as a regional power in Asia. The country escaped from colonisation in the $19^{\text {th }}$ century and was thus able to chart out independent economic policies as a sovereign country (Siddiqui 2015a).

However, some studies have argued that Western Europe was already economically advanced and rich compared to Asia even before the industrial revolution, primarily due to technological progress (Landes 1969). 
Contrary to these claims, Bairoch (1983) estimated the manufacturing sector in selected countries from 1750 to 1953. His work shows that in 1750 the South (i.e. developing countries - he described them as the "Third World") accounted for nearly three-fourths of the world's industrial output. Their share declined to two-thirds in 1800 and three-fifths in 1830 . However, the drastic fall of the developing countries from $60.5 \%$ in 1830 to $20.9 \%$ in 1880 and a further decline to $7.5 \%$ in 1913 was noted, while the advanced economies' (Bairoch included Europe, North America, and Japan) share in world industrial output increased from $39.5 \%$ in 1830 to $79.1 \%$ in 1880 and $92.5 \%$ in 1913 . Bairoch's study took into account levels of industrialisation in terms of volume of manufacturing production per capita. He found that the ratio of manufacturing production per capita in the South fell from $7: 8$ in 1750 to $3: 4$ in $1800,1: 4$ in $1860,1: 8$ in 1880 , 1:17.5 in 1900, and 1:27.5 in 1930 (Bairoch 1993, p. 91).

Table 2 shows the GDP growth rates and also GDP per capita for the 1820 to 1950 period. These figures are based on Maddison's estimates of GDP growth and GDP per capita in 1990 US dollars by regions and countries for selected years. For Western Europe the growth rate in 1820-1870 was $1.68 \%$ annually, which rose to $2.2 \%$ then fell to $1.19 \%$ annually. Japan managed to raise GDP growth from $0.4 \%$ in $1820-1870$ to $2.21 \%$ in $1913-1950$, as shown in Table 2. However, a sharp decline was seen in the share of Asia in world GDP for the same period. The growth performance of China and India in the 1820-1870 and 1913-1950 periods was worse compared to other regions, as shown in Table 2 . The share of Africa in the world growth rate was slightly higher for the later period. Growth performance within the South group of countries was not all similar. For example, in contrast to Asia, the share of Latin America in world GDP growth from 1870 to 1950 had witnessed higher growth rates than even Western Europe. This is because these countries were free and independently charted out their economic policies.

In Western Europe the spread of the industrial revolution also led to growing demand for capitalist forms of organisation, of production in factories employing workers, and the constant drive to raise productivity through the division of labour and technology.

To understand levels of economic integration of the South with the North, we have to look at trade and investment. The data shows that exports from the South rose from $\$ 1.7$ billion in 1900 to $\$ 7.9$ billion in 1928 and again to $\$ 15.4$ billion in 1948 , while at the same time imports also rose from $\$ 1.5$ billion to $\$ 6.5$ billion and $\$ 14.9$ billion, respectively. Measures to liberalise 
trade in the colonies led to the rapid growth of their trade (i.e. both exports and imports) between 1870 and 1913 (Bagchi 1984).

Table 2. Growth Rates in the World Economy by Region, 1820-1950 (in \% per annum)

\begin{tabular}{l|c|c|c|c|c|c|c}
\hline \multirow{2}{*}{ Specification } & \multicolumn{5}{c|}{ GDP } & \multicolumn{3}{c}{ GDP per capita } \\
\cline { 2 - 7 } & $1820-1870$ & $1870-1913$ & $1913-1950$ & $1820-1870$ & $1870-1913$ & $1913-1950$ \\
\hline Western Europe & 1.68 & 2.12 & 1.19 & 0.99 & 1.34 & 0.76 \\
\hline Western Offshoots & 4.31 & 3.92 & 2.83 & 1.41 & 1.81 & 1.56 \\
\hline Eastern Europe & 1.41 & 2.33 & 0.86 & 0.63 & 1.39 & 0.60 \\
\hline Former USSR & 1.61 & 2.40 & 2.15 & 0.63 & 1.06 & 1.76 \\
\hline Japan & 0.41 & 0.44 & 2.21 & 0.19 & 1.48 & 0.88 \\
\hline \multicolumn{7}{|c|}{ The South } \\
\hline China & -0.37 & 0.56 & 0.04 & -0.25 & 0.10 & -0.56 \\
\hline India & 0.38 & 0.97 & 0.23 & 0.00 & 0.54 & -0.22 \\
\hline Africa & 0.75 & 1.32 & 2.56 & 0.35 & 0.57 & 0.90 \\
\hline Latin America & 1.22 & 3.52 & 3.39 & -0.04 & 1.86 & 1.41 \\
\hline
\end{tabular}

Source: Nayyar (2013, p. 22), Maddison (2003, 1998).

Moreover, a large proportion of trade from the colonies consisted of inter-sectoral trade, where primary commodities were exchanged for manufactured goods. Britain, being highly advanced in manufactured goods and technology, exported finished goods i.e. high value products, while it imported raw materials i.e. low value commodities, from its colonies in Asia and Africa. Another key element of the first period of globalisation is foreign capital investment. Here we find that the stock of foreign capital inflows into Asia, Africa, and Latin America rose from \$5.3 billion in 1870 to $\$ 11.3$ billion in 1900 , to $\$ 22.7$ billion in 1914 , and again to $\$ 24.7$ billion in 1928 (Maddison 2003).

Both patterns of trade and capital investment show that from the second half of the $19^{\text {th }}$ century the colonies were integrated as suppliers of raw materials and markets for finished goods from Britain. Finally, the destruction of manufacturing sectors in Asia paved the way for the expansion of markets for British finished goods in Asia. As Nayyar (2013, p. 32) summarised it: "Between 1830 and 1913, the share of Asia, Africa, and Latin America in the world of manufacturing production, attributable mostly to Asia, in particular China and India, collapsed from $60 \%$ to $7.5 \%$, 
while the share of Europe, North America, and Japan rose from $40 \%$ to $92.5 \%$, to stay at these levels until 1950 . The industrialisation of Western Europe and the de-industrialisation of Asia during the $19^{\text {th }}$ century were two sides of the same coin. It led to the Great Specialisation, which meant that Western Europe, followed by the United States, produced goods while Asia and Latin America produced primary commodities".

There was no reason why industrialisation and the development of capitalism would not have taken place in a country like India if it had not been colonised by Britain. For instance, the two most important industries responsible for industrial development in the $19^{\text {th }}$ century - which took place with the discovery of steam - were railways and shipping. Prior to the colonisation of the Indian economy we find not only textile industries were adversely affected, but also the shipyards in Bombay. These shipyards were strangled by the British Registry Act of 1786 , which placed severe limitations on Indian shipping. There were no shortages of Indian technicians who would have learned the necessary skills at work and thus would have successfully improved their traditional skills. Karl Marx hoped that with the introduction of railways in India, they would become "truly the forerunner of modern industry". His optimism was based on the belief that trains could not operate "without introducing all those industrial processes necessary to meet the immediate and current wants of the railway locomotive" (Baran 1957). As Paul Baran (1957) pointed out the imperial powers did not encourage comprehensive industrialisation in their colonies and it was contrary to their economic and strategic interest to do so. Therefore, according to him, political and economic factors dictated by colonialism and imperialism led to the creation of an unequal world.

\section{The Issue of Free Trade}

Neoclassical economists have emphasised that free trade is the only option through which global poverty and inequality between countries can be removed. Trade and economic liberalisation have become a new mantra of the $21^{\text {st }}$ century (Girdner \& Siddiqui 2008). The success of the East Asian economies and more recently the Chinese upsurge in economic growth are said to be largely due to export-led policies and market reform measures taken initially in 1978 (Siddiqui 2009). A number of economists have disagreed with such propositions, however, arguing that both liberalisation of the economy and state intervention to promote domestic businesses created the Chinese miracle (Siddiqui 2016a, Rodrik 2011). 
Economic historians have concluded that free trade imposed by Europeans in the colonies has brought dramatic socio-economic changes at both the national and international levels and facilitated a new form of international division of labour. The nationalists' argument is that in Asian and African countries the imperatives of "free trade", whether imposed on China by gun boat or, as in the case of India, by outright occupation, had a devastating effect. Long standing Chinese business clans were as important in spreading trade across South East Asia as bourgeois capitalists in Hamburg, London, and New York. European domination over the world's economy and people became obvious by the end of the $19^{\text {th }}$ century, at which time a large part of the South and of humanity had been converted into long term losers in the scramble for resources and dignity (Cain 2006). However, to understand the whole truth of "free trade", we must analyse the experiences of the developing countries, especially in the $19^{\text {th }}$ and first-half of the $20^{\text {th }}$ century, when the present developing countries were European colonies and semi-colonies and "free trade" policy was imposed on them (Siddiqui 2018a).

Britain imposed tariff duties into its domestic markets on imports of textiles cloths from India, while no such protection was provided to Indian textiles producers in India in the early $19^{\text {th }}$ century. As a result, manufacturing collapsed and the urban population fell in India. For example, the population of Dacca, which was once a great centre of muslin production, fell by $90 \%$ within a very short period. Therefore, instead of being an exporter of textiles and other industrial products, India began importing British textiles, and India's export share of world markets fell from $27 \%$ in 1815 to $2 \%$ in 1840 (Maddison 1998).

Indian manufacturing in the early $19^{\text {th }}$ century had the capability of successfully challenging British textiles, which were then the leading sector of the British economy's leap into industrialisation (Siddiqui 1990). The British government thus extended protection to their textile producers against imported textiles from India. For example, by 1814, Britain placed tariffs of $70 \%$ to $80 \%$ on all imported textiles from India, and as a result Indian textiles became un-competitive price-wise in the British market i.e. became very expensive and therefore unattractive to the consumer. At the same time, the colonial government did not introduce any tariffs to protect Indian textiles, leading to the flooding of British textiles into Indian markets. Because there were no tariffs against the export of raw cotton from India, there was a dramatic rise of such exports. The traders of the East India Company (i.e. the company that was exclusively owned by British 
shareholders) simply switched from buying Indian textiles to buying raw cotton to sell into British markets. Despite having locally available raw materials such as cotton, long experience, and cheap labour, India no longer produced cotton textile products, but rather exported raw cotton and imported cotton textiles from Britain. The cotton products imported from Britain increased from just 1 million yards in 1814 to 53 million yards in 1844 . And also the number of Indian textile workers (spinners and weavers) fell from 6.3 million to only 2.4 million between 1800 and 1911 (Bagchi 1984).

Those countries that were able to escape direct colonisation were still not protected from the adverse effects of free trade treaties. In fact, such treaties then encouraged and made it profitable for them to produce and export raw materials. Low tariffs along with falls in shipping costs undermined the development of indigenous industries in Asia and Latin America capable of competing with Britain. For example, Egypt and Turkey, both under British pressure, drastically reduced import restrictions. As a result, Turkey's textile imports rose dramatically after Britain signed a treaty with Turkey in 1838, according to which the country was forced to open up its economy and keep import duties to a maximum of 5\% (Rodrik 2011).

It is assumed that trade liberalisation will lead to income convergence between countries. Garima Siwach (2016) studied the effect of liberalisation on the per capita income of 19 developing countries that opened up their economies in the 1980s and 1990s. The study compared the trade effects on convergence rates by looking at patterns of pre- and post-liberalisation. Such studies of growth and convergence can have a significant impact on long-term growth policies of an economy by illustrating the implications for poverty, which is the most important policy area the countries of the developing are seeking to address. Siwach (2016, p. 118) concludes that "there is no significant change in convergence that can be attributed to trade liberalisation. Through a first difference analysis that estimates convergence rates between trade groups before and after liberalisation, we find no significant change in convergence for developing countries towards their major partners of trade. The results are robust when large country biases are taken care of as well". Moreover, the convergence theory also emphasises the flow of technology from the rich to the poor countries. There is no doubt that open trade leads to increased knowledge dissemination, but this process needs to be accompanied by domestic polices on infrastructure, education, and institutional settings. As a number of studies have pointed out, trade liberalisation fosters spill-over effects and raises productivity and income 
convergence in those countries that had invested in human capital, including higher levels of literacy rates (Stiglitz \& Charlton 2006, Siddiqui 2016b).

It is said that developing countries have an advantage because they can exploit existing technology without bearing the cost of research and development. It is also claimed that diminishing returns to factor inputs mean that capital returns are higher in the developing countries and there is a larger number of rural workers who are engaged in the low productivity agriculture sector that could be moved to higher productivity manufacturing and service sectors. Neo-classical economists place emphasis on trade relationships and on the assumption that each participant in a market has sufficient resources to withdraw from the market if they do not agree on the prices. However, in this case, indebted peasantry had no such options i.e. they were unable to withdraw from the colonial system (Siddiqui 1990).

Karl Marx came to the conclusion that without protective tariffs against England there could be no economic development of Ireland. His earlier views on the role of "free trade" changed, as he wrote, "The system of protection was an artificial means of manufacturing manufacturers, of expropriating independent labourers, of capitalising the natural means of production and subsistence, of forcibly abbreviating the transition from the medieval to modern mode of production" (Marx 1992, p. 708). In the late $1600 \mathrm{~s}$, Ireland, a British colony, was about to develop woollen industries. This was due to a number of factors including a flow of skilled Catholic immigrants from the Continent and the availability of raw materials. However, English woollen producers saw this as a threat to their own woollen industry and they successfully petitioned the English king to prohibit all exports of woollen textiles from Ireland in the Wool Act of 1699.

Economic development seems to have a strong association with industrialisation i.e. with increasing the share of a country's output and labour force involved in industrial sectors. Wages also seem to be higher in the industrial sector than in the agriculture sector because the application of technology is greater in the former and therefore productivity gains are often easier to achieve. It is assumed that with the expansion of the industrial sector, the contribution of the agriculture sector to the GDP both in terms of its share output and employment declines. It is also said that surplus labour from agriculture can then move to the higher productivity industrial sector. As Amsden (2001, p. 2) argues, "economic development is a process of moving from a set of assets based on primary products, exploited by unskilled labour, to a set of assets based on knowledge, exploited by skilled labour". Also, the experience of the successful East Asian economies 
tells us that industrialisation has played an important role in reducing the burden of productivity from agriculture to changes in the patterns of trade (Siddiqui 2012b). A modernised economy with an expanding industrial sector is expected to increase the proportion of exports of manufacturing goods, while at the same time reducing the exports of primary commodities as a proportion of total exports. Primary commodities will be replaced through greater diversification of the economy and exports will include a higher proportion of manufacturing goods and services. This would also mean exports will consist of an increased proportion of higher value products.

This is achieved, in part, by consistent government efforts to increase investment in education, skills, and training of the labour force along with increased investment in infrastructure such as roads and ports. In other words, changes in social and economic policies are also needed. Barriers to change in both internal and external environments must be dealt with so that targeted polices can be achieved (Stiglitz \& Charlton 2006). And also the gains in recent decades by the developing countries are taking place due to the outsourcing of industrial production by multi-national corporations (MNCs) aimed at exploiting low wages in these countries.

The shift of manufacturing industries in recent decades from the advanced economies to the developing countries has made a huge impact and a structural change in the economies of especially some East Asian countries. Despite the shift of industry to the developing countries, the global MNCs of the developed world continue to hold almost a monopoly in the development of the most advanced technologies and new products. This is manifested in the inability of developing countries, except China, to catch up economically with the advanced economies. For example, from 1970 to 1989, the average annual per capita GDP of the developing countries, excluding China, was only $6 \%$ of the per capita GDP of the G7 countries (US, Japan, Germany, UK, France, Canada, and Italy). Further, for the 1990 to 2013 period, this slightly declined to 5.6\%. Moreover, for the forty-eight least advanced economies, average annual per capita GDP as a share of that of the $\mathrm{G} 7$ declined during the same period from $1.5 \%$ to only $1.1 \%$ (UNIDO 2016).

In the 1980s the developing countries' share of world industrial employment was $52 \%$, which had risen to $83 \%$ by 2013. The share of worldwide inflows of foreign capital (i.e. FDI) into the developing countries also increased from 33\% in 2000 to $51 \%$ in 2010 and further to $61 \%$ by 2014 (IMF 2016). However, if China is included in the developing countries, the average annual per capita income of developing countries as a percentage 
of that of the G7 rises from $4.7 \%$ in $1970-1989$ to $5.5 \%$ in $1990-2014$ (IMF 2016).

The eras of capitalism since the mid-20 $0^{\text {th }}$ century could be categorised as follows: the golden age of capitalism (1948-73); transition (1973-80); and neoliberalism (1980-?). Capitalism at this stage of development requires (a) the further integration of global markets and production activities to increase accumulation and (b) the exploitation of those regions that are either less advanced and / or not currently within its domain. Globalisation appears to be the process of a greater degree of integration of economic activities among countries (Siddiqui 1998). This includes increased levels of goods and capital movement via international flows. It also means the greater openness of national markets and a reliance on trade to achieve economic prosperity. The attempts that were made to integrate economies can be divided into three periods, as explained below.

The first period (1870-1914) saw tariffs lowered among countries as a result of colonisation and a reduction in transport costs. During this period the rapid expansion of railways and telegraphs took place. This period also witnessed an average increase in GDP growth of only $0.5 \%$ per annum. This was driven under the leadership and control of European countries and their businesses as they increased their ownership of resources and influence to a very high degree compared to the past. During the first phase of globalisation, only a few European, North American and "New World" (white settlement colonies such as Argentina, Canada, Australia, and New Zealand) countries showed convergence among themselves, while the income differences between them and the rest of the developing countries widened sharply. The most important thing that occurred in this period was the international division of labour, where colonial powers became exporters of capital and technology, while the colonised countries became specialised in the production and supply of primary commodities.

During this first period both public and private investment was meagre in the colonies, especially in agricultural sectors such as irrigation and in the technological progress needed to raise yields and to raise land productivity. In India, for example, Sivasubramonian (1960) and Blyn (1966) have both found that the rate of increase of total agricultural output for the first half the $20^{\text {th }}$ century was negligible. India had carried out three distinct policy measures to maintain income deflation on the Indian population. The first policy imposed was very high land rent charges, which led to the phenomenon of so-called "drain surplus". The second was a deliberate attempt to undermine Indian manufacturing, i.e. the destruction 
of handicraft production, which is known as the de-industrialisation of the Indian economy. The third was the import of industrial goods from Britain (Siddiqui 1996).

The second period (1945-1980) witnessed a further decline in transport costs and increases in productivity in the West. International trade rose as the Western economies were progressively opened for trade and capital investment. We also find that the colonies became independent and assigned a greater role to the state in managing the economy. They undertook a policy of domestic industrialisation, with little attention paid to the sources of financing. As a result economic growth increased, but there was a financial crisis, while at the same time the population was rising at higher rate than in the pre-colonial period due to the greater availability of medicine and food. Agricultural output increased much faster compared to the pre-independence period. The state undertook a number of measures to protect farmers, such as protecting them from global price fluctuations, providing subsidies for electricity, fertilizers, credits, public funds for research into the development of new seeds, and also assured remunerative prices through the public procurement of certain crops.

The third period (1980-) witnessed the increasing integration of the global economy, not only among the Western countries but also developing countries joining in through increased trade and foreign capital investment. However, in the 1980s and 1990s most of the developing countries had to adopt neoliberal reforms imposed by international financial institutions such as the World Bank and the IMF, known as "structural adjustment programmes" (SAP), due to their heavy borrowings in the 1980s and subsequently their inability to repay loans, which resulted in debt crises and macroeconomic imbalances. The adoption of SAPs also included the opening up their domestic markets to foreign goods, technology, and capital. Some of the developing countries saw rapid structural change in their economies and increased production and export of manufacturing goods, especially the East Asian countries. However, for most of the developing countries, neoliberalism, which SAP is a part of, "has a strong family resemblance to dependency theory in identifying the logic of unequal power relations, blocked development and adverse incorporation in the global economy. Firstly, the very nature and dynamics of structural adjustment and conditionality-based development aid reflects and reproduces the deeply unequal and coercive relationship between rich and poor countries. Secondly, it requires poor countries to implement self-destructive economic policies, including open door trade and investment regimes that result in 
de-industrialization and vulnerability to speculative financial flows. Thirdly, it pushes developing countries backwards in development to a colonial-era structure of primary commodity exports, locking them into a vulnerable and dependent position of enduring weakness" (Venugopal 2015, p. 176).

\section{Globalisation and Economic Liberalism}

The neoliberal policy stance is characterised by the hegemony of international financial capital, where the state acts as an entity that stands almost exclusively with the interests of the corporate sector. Globalisation and neoliberalism limit the developmental policy options of the developing countries, which are pushed aggressively by the WTO and fully backed by the advanced economies. The Trade-Related Aspects of Intellectual Property Rights (TRIPS) agreement has been in force since 1995 and imposes a global standard for protecting and enforcing all forms of intellectual property rights (IPR), including those for patents. The TRIPS Agreement requires WTO Members to provide protection for a minimum term of 20 years for any invention of a product or process. Prior to TRIPS, countries provided only process and not product patents. Product patents provide for absolute protection of the product, whereas process patents provide protection in respect of the technology and the process or method of manufacture.

The Uruguay Round negotiations in 1994 produced the Agreement on Trade-Related Investment Measures (TRIMs). This aims to bring down investment barriers. The agreement is supposed to ensure national treatment by removing domestic content provisions. The General Agreement on Trade in Services (GATS) was signed in 1994. This agreement intends to remove any restrictions and internal government regulations in the areas of service delivery that are considered "barriers to trade". The strategy, for instance, is to transform education into a tradable commodity. The GATS educational agenda has the potential for further privatization to a higher level in education and also opens the door for international competition. The developing countries will be adversely affected in terms of their sovereignty on cultural policy and the quality and accessibility of their public education systems in general (Stiglitz \& Charlton 2006).

These three policy measures on intellectual property rights (TRIPS), on investment measures (TRIMS), and trade in services (GATS) limit the authority of governments in the developing countries. In fact, these regulations expand the options of global companies operating in the 
developing countries. Most of the global companies originate from the advanced economies and will benefit from global market-opening by technology rent-seeking. A structural change in the advanced economies of the last three decades, in which services have become dominant, has inspired the West to seek protection for these interests. The multilateral agreements pushed by the Uruguay Round prevent the developing countries from pursuing any kind of industrialisation or economic diversification policies as adopted by the East Asian countries (Siddiqui 2015b). It is clear that in the global political economy where bargains and deals are struck, developed and developing sides are not equally strong.

The advanced economies are the net producers of patentable knowledge, while developing countries are a net consumer, meaning that rent will flow from developing countries to the advanced economies. The proponents of TRIPS argue that higher profits acquired by the companies will lead to more investment in technology and innovation and ultimately consumers in the developing countries will benefit. However, such arguments ignore the fact that investment and innovation depend on many factors, including competitive environments and profits. Past experiences show that this is not always the case. Despite the fact that some assurances have been given to address humanitarian concerns in health areas, no firm commitments on technology transfer and industrialisation have been made to the developing countries. The GATS emphasis is on trade in services, including banks, public utilities such as drinking water, sanitation, education, and so on. The GATS require "national treatment", meaning all service companies must be treated as domestic companies. This means that developing countries will not be able to protect their domestic companies against well-resourced global companies.

It appears that in recent years the imposition of neoliberal economic reforms in the developing countries, especially in highly indebted ones, means that the effective withdrawal of the state from domestic policy will make agriculture an economically unviable occupation for a large number of farmers - a situation very different from the immediate post-colonial policies.

As a result of two centuries of European control and domination of the developing countries, by 1950 their total GDP share had shrunk to only $27 \%$, while they still accounted for more than two-thirds of the world's population. In the 1950s, China and India together produced only $9 \%$ of global GDP, with more than two-thirds of the world's population. For instance, at the time of independence in 1947, Indian manufacturing accounted for only $7 \%$ of its GDP and only $2 \%$ of the labour force was employed in industries. 
In contrast, the advanced economies' share of global GDP rose sharply by 1950 , more than doubling to nearly $70 \%$, with a share of the world's population of less than $28 \%$ (Siddiqui 2010).

The question arises: did trade liberalisation play a role in reducing inter-country and international inequality? To understand this, we must look to what extent trade performance is linked to growth performance. If we assume that growth in world trade is an important determinant of trade performance, then there is a need to analyse the cross-country patterns of trade performance in order to understand fully the linkage to changes in inter-country and international inequality.

Multilateral institutions such as IMF, World Bank, and WTO have claimed that trade stimulates growth. Such conventional wisdom finds support among neoclassical economists, who argue that trade promotes specialisation and allows for economies of scale due to increasing market size and facilitates the global diffusion of technology.

A more comprehensive way to look at the trade-GDP ratio is that an increase in this ratio is interpreted as improvement in trade performance and vice versa. Then the question arises: should we look at the growth of GDP or the growth of per capita GDP? The standard textbook approach would be that trade affects changes in per capita GDP. Increased trade raises factor productivity and standard trade theory assumes full employment, so that a rise in trade can affect growth only through factor reallocation. However, full employment does not exist in the developing countries. Once we abandon this assumption, then increased trade will lead to increased investment as openness encourages capital flows. But this does not necessarily mean that all capital will be invested: some might be used in speculation and can encourage capital flight, which could have an adverse effect on domestic investment.

As regards analysis of the effect of trade liberalisation on trade performance, Ghose (2004, pp. 240-41) concluded that "we should need to construct a measure of change in openness over the period for each of the countries and then study the relationship between this change and the change in trade performance (...) however, construction of appropriate indices of openness has proved extremely difficult, and much research is required (...) [in] the mid-1980s virtually all countries of the world implemented trade liberalisation policies. However, neither the initial trade regime nor the liberalisation policies were the same across countries (...) The effect of liberalisation on trade performance has been quite varied 
across countries (...) trade liberalisation had a more favourable effect on the growth performance of populous countries than on that of small countries".

\section{Convergence or "Catching Up"?}

In the mid-19 $9^{\text {th }}$ century when Britain's manufacturers faced stiff competition from the then established companies of Holland, Friedrich List observed: "It is very clever common device that when anyone has attained the submit of greatness, he kicks away the ladder by which he has climbed up, in order to deprive others of the means of climbing up after him (...) Any nation which by means of protective duties and restrictions on navigation has raised her manufacturing power (...) can do nothing wiser than to throw away ladders of her greatness, to preach to other nations the benefits of free trade (...)" (List 1966, p. 368).

GDP per capita in developing countries rose from \$209 in 1970 to $\$ 3715$ in 2014, while in the West, as a proportion of GDP per capita, it decreased from $7.3 \%$ in 1970 to $4.9 \%$ in 1990 , but increased to $9.4 \%$ in 2014 . In fact, in the last four decades, GDP per capita in the developing countries as a ratio of that in industrialised countries rose from 1:13.6 in 1970 to $1: 10.6$ in 2014. The population of the developing countries more than doubled from 2.7 billion in 1970 to 5.7 billion in 2014 (IMF 2016, Siddiqui 2016c).

Between 2002 and 2007 the growth rates of both advanced and developing economies accelerated, but then growth sharply declined after the global financial crisis of 2008. Thereafter, the economies of both groups rose briefly in 2010, but soon witnessed a slow-down again. In the early 2000s the US economy experienced rapid growth, which was driven by the availability of consumer debt, primarily housing markets and other consumer durables. It was driven by a finance bubble after the government relaxed bank regulation, thus encouraging banks to be innovative. The US economic boom in the early 2000s boosted demand for goods and capital from abroad. However, such a situation could not continue forever. The boom of the mid-2000s initiated by innovation in finance was able only to build an unsustainable bubble, while at the same time wages stagnated and inequality widened. This led to a reconsideration of what Keynes called "lack of aggregate demand" (Siddiqui 2017b).

After the global financial crisis most of the advanced economies followed expansionary fiscal policies, but these were discarded as soon as the economies began to pick up and the crisis was thought to have been managed. Once again the advanced economies reverted to the neoliberal 
dogma that monetary policy was the preferred instrument and the reduction in interest rates was expected to restore confidence in the economy and encourage investment and growth. Moreover, monetary policy tends to be rather limited, especially when focused only on "quantitative easing" and cheap credit through zero interest rates. At the same time, the purchasing power of those people whose marginal propensity to consume is known to be higher suffered through welfare cuts and wage stagnation. In developing countries the credit bubbles were created in response to the 2008 crisis and declining demand for their exports. The credit to GDP ratio and non-performing loans have risen sharply since 2010 (Siddiqui 2012a).

Tables 3 and 4 show the per capita GDP growth of the developed and developing economies from 1978 to 2015. Here again we find China at the top of the list with an average annual growth of $7.4 \%$, and this growth compared to the US is estimated to be $461 \%$.

Table 3. Per Capita GDP - Fastest Growing Economies from 1978 to $2015^{*}$

\begin{tabular}{c|l|c|c|c}
\hline Rank & \multicolumn{1}{|c|}{ Country } & $\begin{array}{c}\text { Total increase } \\
(\%)\end{array}$ & $\begin{array}{c}\text { Average annual } \\
\text { growth }(\%)\end{array}$ & $\begin{array}{c}\text { Growth compared } \\
\text { to United States (\%) }\end{array}$ \\
\hline 1 & China & 1,396 & 7.4 & 461 \\
\hline 2 & Myanmar & 660 & 5.2 & 326 \\
\hline 3 & South Korea & 632 & 5.1 & 319 \\
\hline 4 & Taiwan & 566 & 4.8 & 299 \\
\hline 5 & Vietnam & 484 & 4.4 & 272 \\
\hline 6 & Thailand & 443 & 4.1 & 256 \\
\hline 7 & India & 431 & 4.0 & 251 \\
\hline 8 & Sri Lanka & 430 & 4.0 & 235 \\
\hline 9 & Singapore & 418 & 3.9 & 230 \\
\hline 10 & Cambodia & 394 & 3.8 & 224 \\
\hline 11 & Hong Kong & 382 & 3.7 & 213 \\
\hline 12 & Malaysia & 369 & 3.6 & 204 \\
\hline 13 & Indonesia & 346 & 3.4 & 184 \\
\hline 14 & Chile & 330 & 3.3 & \\
\hline 15 & Mozambique & 293 & 2.9 & \\
\hline
\end{tabular}

* Calculated in PPP of 2011 converted to 2014 prices.

Source: calculated from the Conference Board Total Economy Database 2015; World Bank (2016). 
Table 4. Total Per Capita GDP Growth in Advanced Economies, 1978-2015*

\begin{tabular}{l|c|c|c|c|c}
\hline Country & $\begin{array}{c}\text { Total growth } \\
1978-2015 \\
(\%)\end{array}$ & $\begin{array}{c}\text { Annual } \\
\text { average } \\
\text { growth (\%) }\end{array}$ & $\begin{array}{c}\text { Growth rate } \\
\text { as \% of China }\end{array}$ & $\begin{array}{c}1978-\text { per } \\
\text { capita GDP } \\
\text { as \% of China }\end{array}$ & $\begin{array}{c}2015-\text { per } \\
\text { capita GDP } \\
\text { as \% of China }\end{array}$ \\
\hline Japan & 182 & 1.6 & 22 & 2,078 & 275 \\
\hline Germany & 177 & 1.6 & 21 & 2,625 & 340 \\
\hline UK & 189 & 1.7 & 23 & 2,123 & 298 \\
\hline France & 156 & 1.2 & 16 & 2,465 & 286 \\
\hline US & 180 & 1.6 & 22 & 3,010 & 404 \\
\hline China & 1,396 & 7.4 & - & - & - \\
\hline
\end{tabular}

* Calculated in PPP of 2011 converted to 2014 prices.

Source: Calculated from the Conference Board Total Economy Database 2015; World Bank (2016).

Share developing regions in global GDP

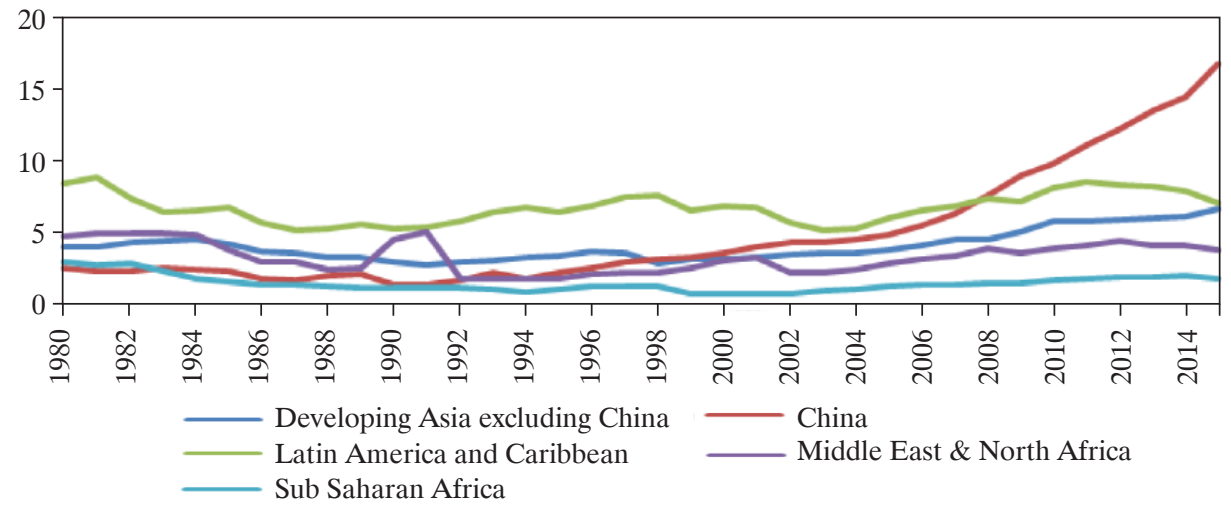

Fig. 1. Share of Developing Regions in Global GDP (Current US\$ Prices at Market Exchange Rates)

Source: IMF (2016), IMF database (accessed: 22 June 2017).

Figure 1 shows the changing share of GDP of the major developing regions. Here China is plotted separately to show its growing economic share. China's share in global GDP rose from 3\% to 15\% between 2005 and 2016. This was a time when China's share of global GDP at the market exchange rate rose rapidly to ten percentage points. In fact, such a rapid change in China's share alone explains $87 \%$ of the entire decline of the advanced economies for the period of the last thirty-five years. Figure 1 indicates the changes in share of the largest Asian developing economies excluding China. We find that India's share in global GDP has been the largest and its share 
increased from $1.8 \%$ in 2005 to $3 \%$ in 2015 . However, it is much less than China, whose share is three times India's aggregate share. Indonesia and South Korea's share in global GDP has increased (Siddiqui 2014).

However, if we exclude China, then the share change of other regions paints a different picture. For example, the Latin American region in the 1980s had experienced a decline, which is also known as "the lost decade". The regions' economies recovered in the 1990s and early 2000s. Their share in global GDP rose by 5\% in 2003 to $8 \%$ in 2011, but thereafter began to decline. The Middle East countries had experienced a rise in the share due largely to high oil prices, but for the last 2 years - due to a collapse in oil prices - their share in global GDP has fallen. Sub-Saharan Africa had a long period of stagnation and economic decline i.e. from 1980 to 2002 and since then its share in global GDP has gone up slightly from $1.1 \%$ in 2002 to $2 \%$ in 2015. However, its share in global GDP is still below its 1980s share of 3\%. In short, among the developing regions, only Asia's share in global GDP is rising. Due to the ongoing global recession in the advanced economies, the BRICS countries are also facing slowing economic growth rates and declining export markets (Siddiqui 2016c).

Soon after independence the developing countries saw that industrialisation was imperative to the removal of "backwardness" by increasing productivity and diversifying the economy. To this end nearly all the developing countries adopted import substitution policies in the manufacturing sector. International trade increased after the 1950s in the developing countries.

Exports from the developing countries rose from $\$ 20$ billion in 1950 to $\$ 600$ in 1980 and nearly $\$ 6400$ billion in 2010, but imports rose rapidly as well. The developing countries' share in world exports was $34 \%$ in $1950,19 \%$ in $1970,24.2 \%$ in $1990,31.9 \%$ in 2000 , and $42 \%$ in 2010, while their share of imports in the world economy was $29.6 \%, 18.5 \%, 23.1 \%, 28.8 \%$ and $38.9 \%$, respectively. The sharp rise since 2000 appears to be due to China's growing trade (UNCTAD 2016).

The volume of international trade in goods has increased sharply over the last 10 years (Figure 2a). The developing countries as a group have almost doubled the volume of trade in goods since 2009. But import volumes have been growing relatively more than export volumes for developing countries. However, the opposite has happened in regard to developed countries. The relatively larger increase in the volume of imports can be explained by the increase in consumer demand in developing countries. Growth in trade volumes has slowed down substantially in the last few years, especially in regard to developing countries. In 2015, volume growth 
a)

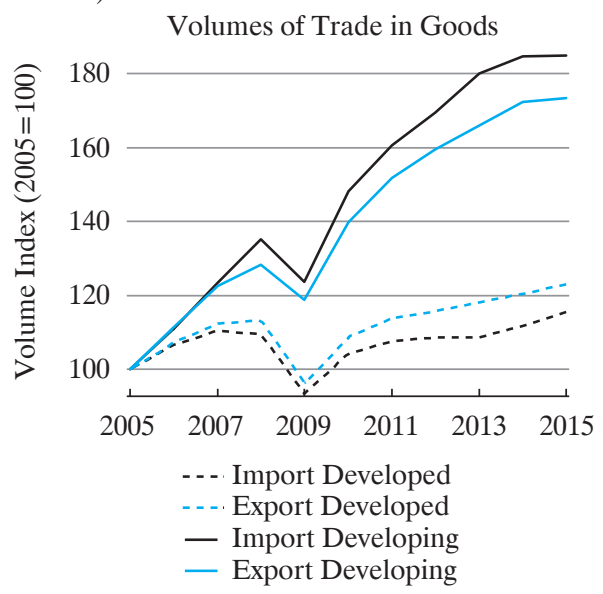

b)

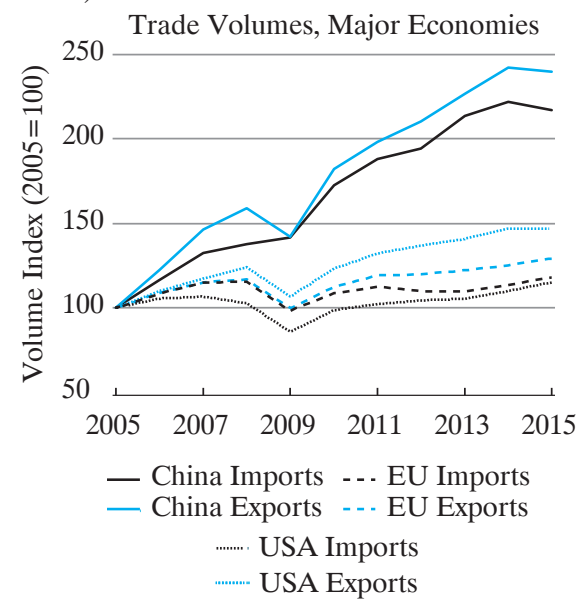

Fig. 2. Volumes of International Trade in Goods

Source: UNCTAD (2016).

was negative in the case of China, both in relation to imports and exports (Figure 2b).

Developed countries' relative importance as suppliers in international markets has declined, but they still account for about half of the value of exports of goods and about two thirds of exports of services. In 2015 developed countries' export of goods was about US $\$ 8$ trillion, while that of services was about $\$ 3$ trillion. In 2015 developing countries' trade came to about US\$ 8 trillion in regard to goods and about US\$ 2 trillion in regard to services. In 2015 the BRICS exported about US\$ 3 trillion in goods and about US\$ 500 billion in services. Less developed countries' contribution to world trade remains minimal, although some increases in the exports and imports of these countries have been recorded over the past decade (UNCTAD 2016).

\section{Concluding Remarks}

During the last three decades there have been huge economic changes globally, and structural changes and changes in patterns of trade have also occurred both in advanced and developing countries. However, some developing countries have achieved faster growth rates than the advanced economies, particularly China, India, Indonesia, and Turkey. These countries constitute a small minority among the developing countries, but 
account for a large proportion of their population. Since independence, in the 1950s and 1960s, the developing countries' share of global GDP has risen and by 2010 their total share was over $42 \%$, double that in the 1970 s. The industrial sector in the developing countries has also grown and their share of value added in global manufacturing output increased from $13 \%$ in 1970 to more than $40 \%$ by 2010 . Moreover, the share of manufactures in developing countries' exports rose from $12 \%$ in 1980 to $63 \%$ by 2010 , nearly half of this consisting of medium and high technology products.

As the Chinese and Indian economies are "catching up" fast, both are re-emerging as the most rapidly growing economies and also as major contributors to overall global output growth in the $21^{\text {st }}$ century. In the recent past the two countries were known as marginal economies, but now China has become the second largest economy after the US, which is a remarkable development of the $21^{\text {st }}$ century. However, the global GDP share of Latin America marginally increased to 8\% between 1970 and 2010, while the share for Africa remained the same i.e. less than 3\% for this period. Africa's share in manufacturing value added in 2011 was only $2 \%$, the same as in 1970.

This paper contributes both theoretical and empirical insights into important issues such as trends in global inequality and in the political economy of developed and less-developed countries (Siddiqui 2019). Theoretically, this study has analysed a number of views of both proponents and opponents on the subject of global inequality. Empirically, the study has examined the existing data to establish the outcomes of neoliberal policies which were initiated four decades ago in most countries. Finally, this article proposes that if we exclude China and India, then global inequality between developed and less developed nations has widened.

The study concludes that colonisation had an enormous negative impact not just on the economies but also on the social and political systems of colonised countries. As a result, their economies fell well behind until the mid-20 ${ }^{\text {th }}$ century. After independence, their economies began to witness higher growth rates than in previous decades. However, most developing countries have not been able to converge with the economies of the West, with the notable exception of the two largest, most powerful and most resistant to the neoliberal policies of global institutions - China and India.

\section{Bibliography}

Amsden, A. (2001) The Rise of "the Rest": Challenges to the West from the Late Industrialising Countries. Oxford: Oxford University Press. 
Anievas, A. and Nisancioglu, K. (2015) How the West Came to Rule: The Geopolitical Origins of Capitalism, London: Pluto Press.

Arrighi, G. (2007) Adam Smith in Beijing Lineages of the 21st Century. New York: Verso, pp. 136.

Bagchi, A. K. (1984) The Political Economy of Underdevelopment. Cambridge: Cambridge University Press.

Bairoch, P. (1983) "A Comparison of Levels of GDP Per Capita in Advanced and Developing Countries: 1700-1980”. Journal of Economic History 43(1): 27-41.

Bairoch, P. (1993) Economics and World History: Myths and Paradoxes. Chicago: University of Chicago Press.

Baran, P. (1957) The Political Economy of Growth. New York: Monthly Review Press.

Blyn, G. (1966) Agricultural Trends in India, 1891-1947: Output, Availability, and Productivity. Philadelphia: University of Pennsylvania Press.

Cain, P. J. (2006) "Character and Imperialism: The British Financial Administration of Egypt, 1878-1914”. The Journal of Imperial and Commonwealth History 34(2): 177-200.

Chang, H. J. (2002) Kicking Away the Ladder: Development Strategy in Historical Perspective. London: Anthem Press.

Davis, M. (2001) Late Victorian Holocausts. London: Verso.

Engels, F. (1990) "Protection and Free Trade. Preface to Speech of the Question of Free Trade, by Karl Marx" in Collected Works of Marx and Engels, vol. 26. New York: International Publishers, pp. 521-36.

Frankopan, P. (2015) The Silk Roads: A New History of the World. London: Bloomsbury.

Ghose, A. K. (2004) "Global Inequality and International Trade". Cambridge Journal of Economics 28(2): 220-246, https://doi.org/10.1093/cje/28.2.229.

Girdner, E. J. and Siddiqui, K. (2008) "Neoliberal Globalization, Poverty Creation and Environmental Degradation in Developing Countries". International Journal of Environment and Development 5(1): 1-27.

Harris, K. (2016) "Making and Unmaking of the Greater Middle East". New Left Review 101: 5-34.

Hyndman, M. H. (1919) The Awakening Asia. London: Cassell \& Co.

IMF (2016) World Economic Outlook, various years. Washington DC.

Jacques, M. (2012) When China Rules the World: The End of the Western World and the Birth of a New Global Order. 2nd ed. London: Penguin Books.

Landes, D. (1969) The Unbound Prometheus: Technological Change and Industrial Development in Western Europe since 1750 to the Present. Cambridge: Cambridge University Press.

List, F. (1966) The National System of Political Economy. Augustus Kelley: New York.

Maddison, A. (1998) Chinese Economic Performance in the Long Run. Paris: OECD, Development Centre.

Maddison, A. (2003) The World Economy: Historical Statistics. Paris: OECD.

Marx, K. (1992) Capital: A Critical Analysis of Capitalist Production, Vol. 1, London: Penguin Classics (first published 1848), pp. 708.

Nayyar, D. (2013) Catch Up: Developing Countries in the World Economy. New Delhi: Oxford University Press.

Parthasarathi, P. (2011) Why Europe Grew Rich and Asia Did Not: Global Economic Divergence, 1600-1850. Cambridge: Cambridge University Press.

Pilger, J. (2002) The New Rulers of the World. London: Verso.

Pomeranz, K. (2000) The Great Divergence: China, Europe and the Making of the Modern World Economy. Princeton: Princeton University Press. 
Rodrik, D. (2011) The Globalization Paradox: Why Global Markets, States, and Democracy Can't Coexist. New York: Oxford University Press.

Rowthorn, R. E. (2008) "The Renaissance of China and India" in P. Arestis, J. Eatwell (eds) Issues in Economic Development and Globalization: Essay in Honour of Ajit Singh. London: Palgrave.

Saville, J. (1969) "Primitive Accumulation and Early Industrialisation in Britain" in R. Miliband, J. Saville (eds) The Socialist Register. Merlin Press.

Siddiqui, K. (1990) "Historical Roots of Mass Poverty in India" in C. A. Thayer, J. Camilleri, K. Siddiqui (eds) Trends and Strains. New Delhi: PPH, pp. 59-76.

Siddiqui, K. (1996) "Growth of Modern Industries under Colonial Regime: Industrial Development in British India between 1900 and 1946". Pakistan Journal of History and Culture 17(1): 11-59.

Siddiqui, K. (1998) "The Export of Agricultural Commodities, Poverty and Ecological Crisis: A Case Study of Central American Countries". Economic and Political Weekly 33(39): A128-A137, 26 September.

Siddiqui, K. (2009) "The Political Economy of Growth in China and India". Journal of Asian Public Policy 1(2): 17-35, Routledge, https://doi.org/10.1080/17516230902734528.

Siddiqui, K. (2010) "Globalisation and Neo-liberal Economic Reforms in India: A Critical Review" in S. K. Pramanick, R. Ganguly (eds) Globalization in India: New Frontiers and Emerging Challenges. New Delhi: Prentice Hall, pp. 219-243.

Siddiqui, K. (2012a) "Developing Countries Experience with Neoliberalism and Globalisation". Research in Applied Economics 4(4): 12-37, https://doi.org/10.5296/ rae.v4i4.2878.

Siddiqui, K. (2012b) "Malaysia's Socio-Economic Transformation in Historical Perspective”. International Journal of Business and General Management 1(2): 21-50.

Siddiqui, K. (2014) "Growth and Crisis in India's Political Economy from 1991 to 2013”. International Journal of Social and Economic Research 4(2): 84-99, https://doi. org/10.5958/2249-6270.2014.00487.5.

Siddiqui, K. (2015a) “Political Economy of Japan's Decades Long Economic Stagnation”. Equilibrium Quarterly Journal of Economics and Economic Policy 10(4): 9-39, https:// doi.org/10.12775/EQUIL.2015.033.

Siddiqui, K. (2015b) "Trade Liberalisation and Economic Development: A Critical Review", International Journal of Political Economy 44(3): 228-247, Taylor \& Francis, https://doi.org/10.1080/08911916.2015.1095050.

Siddiqui, K. (2016a) "International Trade, WTO and Economic Development". World Review of Political Economy 7(4): 424-450, Pluto Journals, https://doi.org/10.13169/ worlrevipoliecon.7.4.0424.

Siddiqui, K. (2016b) "A Study of Singapore as a Developmental State" in K. Young-Chan Kim (ed.) Chinese Global Production Networks in ASEAN. London: Springer, pp. 157-188.

Siddiqui, K. (2016c) "Will the Growth of the BRICs Cause a Shift in the Global Balance of Economic Power in the 21st Century?". International Journal of Political Economy 45(4): 315-338. Routledge: Taylor \& Francis, https://doi.org/10.1080/08911916.2016.1270084.

Siddiqui, K. (2017a) "The Bolshevik Revolution and the Collapse of the Colonial System in India”. International Critical Thought, 7(3): 418-437. Routledge: Taylor \& Francis, https://doi.org/10.1080/21598282.2017.1355743.

Siddiqui, K. (2017b) "Financialization and Economic Policy: The Issues of Capital Control in the Developing Countries". World Review of Political Economy 8(4): 564590, Pluto Journals, https://doi.org/10.13169/worlrevipoliecon.8.4.0564. 
Siddiqui, K. (2018a) "David Ricardo's Comparative Advantage and Developing Countries: Myth and Reality”. International Critical Thought 8(3), https://doi.org/10.10 80/21598282.2018.1506264.

Siddiqui, K. (2018b) “The Political Economy of India's Post-Planning Economic Reform: A Critical Review". World Review of Political Economy 9(2), https://oi.org/ 10.13169/worlrevipoliecon.9.2.0235.

Siddiqui, K. (2019) “The Political Economy of Inequality and the Issue of 'Catching-up". World Financial Review. July/August, pp. 83-94.

Sivasubramonian, S. (1960) "Estimates of Gross Value of Output of Agriculture for Undivided India 1900-01 to 1946-47” in V. K. R. V. Rao et al. (eds) Papers on National Income and Allied Topics. Volume 1. New York: Asia Publishing House, pp. 231-251.

Siwach, G. (2016) "Trade Liberalisation and Income Convergence: Evidence from Developing Countries". Economic and Political Weekly LI(22): 115-120.

Stavrianos, L. S. (1981) Global Rift. New York: William Morrow \& Co.

Stiglitz, J. and Charlton, A. (2006) Fair Trade for All. Oxford: Oxford University Press.

UNCTAD (2016) Key Statistics and Trends in International Trade. UNCTADStat data, http:// unctad.org/en/PublicationsLibrary/ditctab2016d3_en.pdf (accessed: 20 April 2018).

UNIDO (2016) Industrial Development Report. New York: United Nations Industrial Development Organisation, pp. 34-35, https://www.unido.org/fileadmin/user_media upgrade/Resources/Publications/EBOOK_IDR2016_FULLREPORT.pdf. (accessed: 22 June 2017).

Venugopal, R. (2015) "Neoliberalism as a Concept”. Economy and Society 44(2): 165-187, https://doi.org/10.1080/03085147.2015.1013356.

\section{Abstract}

\section{Polityka gospodarcza a globalne nierówności - perspektywa historyczna}

Celem artykułu jest zbadanie możliwości zmniejszenia przepaści ekonomicznej między krajami zaawansowanymi a słabiej rozwiniętymi. Aby to osiągnąć, autor przeanalizował postępy ich gospodarek w ujęciu historycznym. Ważnym pytaniem w XXI w. jest to, czy kraje Azji, Afryki i Ameryki Łacińskiej są zdolne do konwergencji gospodarczej z Zachodem. Aby odpowiedzieć na to pytanie, musimy spojrzeć na ekonomię z perspektywy historycznej. W literaturze często twierdzono, że różnica w podziale bogactwa między krajami bogatymi (uprzemysłowionymi) a biednymi (będącymi pierwotnymi producentami) może zostać zmniejszona lub zlikwidowana w wyniku transferu zaawansowanych technologii z krajów bogatych do krajów biednych. W artykule przeanalizowano to twierdzenie z zastosowaniem metodologii ilościowej opartej na danych pochodzących z międzynarodowych instytucji, takich jak OECD, MFW i Bank Światowy. Okazuje się, że w ciągu ostatnich trzech dekad nastąpiły ogromne zmiany gospodarcze na całym świecie: ustalenia strukturalne i wzorce handlowe zmieniły się zarówno w krajach zaawansowanych, jak i rozwijających się. Mimo że niektóre kraje rozwijające się - szczególnie Chiny, Indie, Indonezja i Turcja - osiągnęły szybsze tempo wzrostu niż gospodarki rozwinięte, większości krajów rozwijających się nie udało się dogonić gospodarek rozwiniętego świata.

Słowa kluczowe: nadrabianie zaległości, konwergencja, neoliberalizm, kraje rozwinięte i rozwijające się, handel międzynarodowy. 